\title{
Infusion of Environment Dimension of ESD into Science Learning Through the RADEC Learning Model in Elementary Schools
}

\author{
Hana Lestari1,2*, Muhammad Ali3 ${ }^{3}$, Wahyu Sopandi', Ana Ratna Wulan 5 \\ ${ }^{1}$ Study Program of Elementary Education, School of Postgraduate Studies, Universitas Pendidikan Indonesia, Indonesia. \\ 2 Primary Education Study Program, Institut Agama Islam Sahid, Indonesia. \\ ${ }^{3}$ Curriculum Development Department, Universitas Pendidikan Indonesia, Indonesia. \\ ${ }^{4}$ Elementary Education Study Program, Universitas Pendidikan Indonesia, Indonesia. \\ ${ }^{5}$ Biology Education Department, Universitas Pendidikan Indonesia, Indonesia.
}

DOI: $10.29303 /$ jppipa.v7iSpecialIssue.817

\section{Article Info}

Received : June $25^{\text {th }}, 2021$

Revised : December 2nd 2021

Accepted: December 7th, 2021

\begin{abstract}
This study aims to provide an overview of infusion of environment dimension of ESD into thematic learning thought the RADEC learning model in elementary schools. This study used a descriptive qualitative approach involving four teachers and twenty students in elementary school Bogor City who were taken based on purposive sampling technique. Data were collected through interviews, observation, and primary school science curriculum documents, which were processed using triangulation techniques. The results of this study indicate that in general, indicators derived from basic competencies can be oriented towards the goal of sustainable education in the dimensions of environmental preservation. Natural science learning which is packaged in thematic learning at the elementary school level can provide opportunities in the process of implementing sustainable development education holistically and comprehensively. The RADEC model can stimulate students to learn actively, not only mastering the concept of environmental conservation but also thinking skills and attitudes in preserving the environment. The RADEC model can be applied in synchronous and asynchronous online learning so it is suitable for use during the Covid-19 pandemic.
\end{abstract}

Keywords: ESD; Environment dimension; Elementary School; RADEC model; Science learning

Citation: $\quad$ Lestari, H., Ali, M. ., Sopandi, W., \& Wulan, A.R. (2021). Infusion of Environment Dimension of ESD into Science Learning Through the RADEC Learning Model in Elementary Schools. Jurnal Penelitian Pendidikan IPA, 7(SpecialIssue), 205-212. https:// doi.org/10.29303/jppipa.v7iSpecialIssue.817

\section{Introduction}

Development not only has positive impacts such as increasing the welfare of people with rapid economic growth, but also has negative impacts such as pollution and environmental damage (Komarudin, et al., 2019; Ali, 2017). Various environmental problems that continue to occur indicate that a commitment from the entire world community is needed to implement sustainable development as a principle in life (Ali, 2017; Eilks, 2015). Sustainable development integrates three dimensions of development that are interrelated, namely the socio- cultural development of the community, economic growth, and utilization and preservation of the environment (Cebrián \& Junyent, 2015). Development is said to be sustainable if the three dimensions are synergized, therefore, it can be understood that sustainable development seeks economic growth and development of a prosperous society while preserving the environment to be able to meet and support the needs of current and future generations.

One of the ways to achieve sustainable development is through education. Education for 
sustainable development or Education for Sustainable Development (ESD) encourages the creation of human resources who can be responsible for environmental preservation amid increasing development (Ali, 2017; UNESCO, 2017). ESD aims to integrate sustainable principles of learning to be able to develop competency knowledge, skills, behavioral attitudes, perspectives, and values that can lead humans to live life by paying attention to life in future generations (Laurie, et al., 2016; Pauw, et al., 2015). Thus, the implementation of ESD is very necessary to develop human competence in creating a sustainable life.

The implementation of ESD in Indonesia from the level of primary school to tertiary education is pursued through the integration of ESD in the school curriculum (Prabawani, et al., 2017). The implementation of ESD in the primary school education curriculum has not been optimally oriented towards the goals of sustainable development. Several research results stated that there were various obstacles faced in implementing ESD in elementary schools, namely (1) The implementation of the 2013 national curriculum in primary schools currently does not explicitly state a commitment to ESD, it is still limited to an understanding of environmental education which is oriented towards reducing negative impacts, and not yet oriented towards sustainable development goals (Listiawati, 2011; Murniningtyas \& Endah, 2018); (2) The implementation of learning principles that are oriented towards the goal of sustainable development in primary schools is not yet optimal.

This can be seen from the learning indicators that have not been oriented towards sustainable development goals, the materials and learning approaches used have not been effective in developing ESD competencies so that they have a weak impact on the formation of understanding, thinking skills, and sustainable awareness behavior of elementary school students (Supriatna, et al., 2018); (3) Elementary school teachers' understanding is still very simple about the concept of sustainable development (Birdsall, 2015).

One of the innovative learning models that can orientate the goals of sustainable development and develop these three competencies is the RADEC learning model. The RADEC learning model is a learning strategy that can be implemented in science learning with the stages of Read, Answer, Discuss, Explain, and Create. This model has the characteristic of being easy to implement in the learning process because each stage is easy to remember and apply by the teacher (Pratiwi, et al., 2018). This model develops learning based on constructivism theory, where children's cognitive abilities are developed in the Zone of Proximal Development (ZPD) which is the area between actual ability (student's ability to learn independently) and potential ability (student's ability to learn with the guidance of teachers and peers) (Lui, 2012). The development of learning in this ZPD area is an effort to realize quality education for all students with a variety of abilities, from students who need guidance to students with high cognitive abilities. The RADEC model has student-centered learning steps and encourages students to be able to develop their abilities both knowledge, skills, and attitudes holistically and comprehensively (Sopandi, 2019) and become a solution in the application of science learning in online learning mode (Sukardi, et al., 2021). This can be seen from several research results related to the implementation of the RADEC model, including (1) Pratiwi, et al., (2018) suggesting that the RADEC learning model can develop students' conceptual understanding of global warming material, the hypothesis test (t-test) is p $(0.00)<0.05$, there is a difference between a class using the RADEC learning model and a class that does not use the RADEC learning model; (2) Karlina, et al., (2020), examined the RADEC model in developing students 'critical thinking skills, the results showed that there were significant differences in students' critical thinking skills in the material properties of light before and after learning; (3) Sopandi, et al., (2020) stated that the RADEC model can develop students 'creative thinking abilities, the results obtained are significant increases in students' creative thinking abilities for each indicator of creative thinking. The fluency aspect increased by $40.1 \%$, flexibility $43.81 \%$, originality $37 \%$, and elaboration $45.04 \%$; (4) Sukmawati, et al., (2020), argued that after learning with the RADEC model, the character of students was observed to show an attitude of integrity, cooperation, independence, and religion. Each stage of the RADEC learning model stimulates students to carry out activities that develop student character including reading, answering, discussing, explaining, exploring, investigating, and solving problems, and making works (Zandvakili, et al., 2018); (5) Sukardi, (2021), argues that during the current Covid-19 pandemic, the RADEC model is a solution in the application of science learning in online learning mode. The five stages of the RADEC model can be carried out online and offline using online media by utilizing both synchronous and asynchronous multimedia. Synchronous learning is a form of learning with direct interaction between students and teachers as well as using online forums such as conferences and online chats. Whereas asynchronous is a form of learning indirectly (not at the same time) using an independent learning approach (Borup et al., 2019; Richardson, et al., 2020).

Based on some of the research results that have been described, the RADEC learning model is very suitable for the goals and competencies of the ESD that you want to develop, so it is suitable for implementing 
ESD in science learning in elementary schools during the current Covid-19 pandemic. Based on this explanation, this study aims to provide an overview of sustainable development education in the dimensions of environmental preservation through the RADEC model in science learning in elementary schools during the Covid-19 pandemic.

\section{Method}

This study uses a qualitative approach with descriptive methods (Creswell, 2014). Data collection techniques used in this study used interviews, observation of the learning process, and literature study of curriculum documents and learning tools designed by the teacher. The research subjects involved in this study were 4 teachers and 20 students in one of the private elementary schools in Bogor City for the 2019-2020 academic year who were taken by purposive sampling.

The characteristics of the research subjects were (1) primary school teachers who are male and female, have good ICT literacy, have teaching experience of at least 2 years of teaching, and have a background in primary school teacher education; (2) Premilary students who are male and female aged 11-14 years, and are taught by teachers who apply the online teaching strategy of the RADEC learning model. The data collected in this study were analyzed qualitatively through the triangulation method which included data reduction, data presentation, drawing conclusions and data verification to obtain representative research results (Miles \& Hubermen, 2002; Ali, 2019).

\section{Result and Discussion}

\section{Enviroment dimension of ESD in Science Learning}

The results of the analysis of curriculum documents and learning tools designed by the teacher, it was found that (1) science learning in elementary schools was implemented with an integrative thematicbased learning system; (2) in general, indicators derived from basic competencies in science learning can be oriented towards ESD objectives; (3) Basic Competence in the realm of knowledge and skills in science learning implicitly contains the objectives of sustainable development in the dimensions of environmental preservation but has not been explicitly translated into indicators of competency attainment and learning objectives, so a science learning design is needed, with learning indicators oriented towards objectives sustainable development an explicit dimension of environmental preservation.

Based on these findings, ESD-oriented science learning can be developed through indicators of achieving basic competencies that contain the content of sustainable development goals to develop ESD goals. The main objective of ESD is an educational process that can develop knowledge, skills, and attitudes to create a sustainable future. A sustainable future can be achieved if the goals of sustainable development become the principles of community life. The sustainable development goals in the dimension of environmental preservation consist of six objectives, namely (1) handling climate change; (2) clean water and proper sanitation, (3) sustainable consumption and production; (4) sustainable urban and residential development; (5) terrestrial ecosystems and (6) marine ecosystems.

The six development goals can be integrated into science learning by linking science material with themes containing environmental issues and environmental issues that are the main concern of world citizens. Some of the environmental issues presented by the teacher in science learning are adjusted to the goals of sustainable development in the dimensions of environmental conservation, such as dealing with the impacts of climate change, forest fires, clean water, and proper sanitation, waste issues, and their management so that they can build cities and settlements that are healthy and sustainable and so on. The use of environmental issues is used as an effort to improve students 'literacy about the environment, thinking skills to be able to find solutions to environmental problems, and students' concern for the environment around them (Peters, et al., 2014). However, the results of further interview analysis with the teacher show that not all themes in thematic learning can be integrated with the content of sustainable development objectives in the dimension of environmental preservation because not all themes contain science learning content. Thematic learning itself is an integrated learning approach with various competencies from various subjects into various themes (Lestari \& Siskandar, 2021; Webb, P. I. \& Pearson, 2012). So, each theme does not necessarily contain every basic competency in science learning.

One of the themes contains the basic competencies of science learning and can be aligned with the objective of sustainable development in the dimensions of environmental preservation, namely basic competencies on theme 8 regarding "our friend's environment" for grade V students. Our Friends "can be described as Table 1. 
Table 1. Formulation of Basic Competencies and ESD Oriented Learning Indicators

\begin{tabular}{|c|c|c|c|}
\hline Dimensions & $\begin{array}{l}\text { Sustainable } \\
\text { Development } \\
\text { Goals }\end{array}$ & $\begin{array}{l}\text { Basic Competencies of } \\
\text { Thematic Learning }\end{array}$ & Indicators of ESD Oriented Learning \\
\hline Enviroment & $\begin{array}{l}\text { Clean Water, } \\
\text { Consumption and } \\
\text { Production } \\
\text { sustainable, } \\
\text { Climate change }\end{array}$ & $\begin{array}{l}\text { 3.8. Analyze the water } \\
\text { cycle and its impact on } \\
\text { events on earth and the } \\
\text { survival of living } \\
\text { things } \\
4.8 \text { Create work on } \\
\text { water cycle schemes } \\
\text { based on information } \\
\text { from various sources }\end{array}$ & $\begin{array}{l}\text { - Analyze the water cycle and the availability and } \\
\text { management of clean water and sustainable sanitation for all. } \\
\text { - Identify sustainable consumption behavior } \\
\text { - Describe ways of preventing and managing the impacts of } \\
\text { climate change } \\
\text { - Making works on the water cycle and its impact to encourage } \\
\text { the provision of clean water sources to settlements in urban } \\
\text { areas. } \\
\text { - Create behavioral works on prevention, reduction, recycling, } \\
\text { and reuse of natural resources } \\
\text { - Creating work on behavioral prevention and mitigation of } \\
\text { climate change impacts }\end{array}$ \\
\hline
\end{tabular}

The objective of sustainable development in the dimension of environmental preservation which can be oriented to this theme consists of three objectives, namely addressing climate change, clean water, and proper sanitation, and sustainable consumption and production. Meanwhile, the formulated indicators are indicators of competency attainment in the realm of knowledge and skills. Knowledge of nature and understanding of the sustainability of natural resources to support life is one of the fundamental aspects in developing students' ecological intelligence (Goleman, D., \& Barlow, 2012; Lestari \& Widodo, 2021; Supriatna et al., 2018). Students need to master knowledge because it is the basis for inculcating attitudes, and habituation of environmental conservation behavior. Therefore, in addition to facilitating students to master knowledge, teachers need to instill attitudes and familiarize students with sustainable behavior in preserving the environment.

Based on the indicators that have been formulated as oriented towards sustainable development goals in Table 1, the teacher can instill attitudes and values through habituation in the learning process in schools based on the three goals of oriented sustainable development. The habituations that can be instilled include (a) Getting students used to writing on two sides of the paper to save on the use of paper whose main material is made of wood; (b) Familiarize students with bringing drinking containers to school to reduce plastic waste; (c) walking or riding a bicycle when the destination is close by minimizing the use of petroleum; (d) Conserving the use of clean water; (e) Washing hands with soap and running water; (f) Turns off electricity when not in use. This habit is carried out to instill an environmentally friendly attitude.
Infusion of Environment Dimension of ESD into Science Learning Through the Radec Learning Model

After obtaining an ESD-oriented science learning design, then implementation in thematic learning is carried out. The selection of learning models in implementing ESD is a matter that greatly influences the achievement of the development goals of the dimensions of environmental preservation and the achievement of developing ESD competencies which include students' knowledge, skills, and attitudes towards environmental preservation. Therefore, we need a learning model that can stimulate students to develop these three competencies maximally. In addition, currently, the learning process is being carried out online during the Covid-19 pandemic. So, it is necessary to select a learning model that can be applied in online learning.

In this study, ESD-oriented science learning was implemented through the RADEC learning model. The RADEC model, which consists of five stages, namely Read, Answer, Discuss, Explain, and Create, can stimulate students to learn actively, not only mastering concepts but skills and attitudes to preserve the environment sustainably. This can be seen from the results of observations and interviews with teachers and students regarding the implementation of the RADEC model in the ESD-oriented science learning process.

Based on the results of observations and interviews, the findings obtained were that the RADEC model could be applied to online learning during the Covid-19 pandemic. The five stages of this model are carried out online using online media by utilizing multimedia both synchronous and asynchronous. Even though it is done online, the five stages of this model can facilitate and stimulate students to develop knowledge about environmental conservation sustainably, critical and creative thinking skills to find ideas to be able to find solutions in overcoming environmental problems and habituation of attitudes and behaviors in sustainably preserving the environment. 
In the first stage, namely the reading stage, the teacher provides instructions for students to read textbooks and various references according to concepts that are studied independently at home. Instructions for reading are given by the teacher before the learning process is carried out, and usually carried out one week before theme eight is taught, namely at the end of the learning process on theme seven. Reading activities can stimulate students to familiarize themselves and develop literacy skills related to environmental preservation. The activity of reading various texts, both fiction and non-fiction, which depict examples of sustainable behavior regarding environmental preservation for the present and the future, stimulates students to tend to act like what is exemplified in the reading material. This has a positive impact on students because through reading activities students will have constructed knowledge and understanding independently so that during the learning process, students already have provisions for understanding to be better explored, as well as provide habituation for students to behave as exemplified in the text. reading so that environmental conservation behavior can be grown (Lestari, et al., 2020; Siti, 2016).

After reading activities, the second stage is students answering pre-learning questions given by the teacher. The pre-learning questions developed contain concepts regarding sustainable development in the dimensions of environmental conservation which are presented in student reading materials at the reading stage. The teacher stimulates students to answer prelearning questions based on the knowledge gained at the reading stage. Pre-learning questions are given online via the google form platform asynchronously. Google forms are one of the features in google classroom (Dhawan, 2020; Xiaoqiao, 2020). Pre-learning questions that have been answered are then uploaded within a certain period determined by the teacher. The prelearning questions given by the teacher are used to stimulate students to understand the reading and the concepts to be studied. Through this pre-learning question, the teacher can collect and classify the level of difficulty of concepts based on students 'answers, so that they can see the extent of students' knowledge about environmental conservation so that the teacher can select all concepts to choose which concepts will be discussed further, namely difficult questions and deserves to be discussed. At this stage also, students practice building the character of initiative or independence to find answers based on the sources of information they read (Rahmadani, et al., 2021; Setiawan, et al., 2020).

The third stage is the discussion stage, students discuss and agree on the answers to the pre-learning questions given by the teacher so that students get an agreement on the correct answer. The platforms used by the teacher in the Discussion stage are Google Classroom and Google Meet. Based on the results of the interview, the findings obtained were that the teacher had difficulty carrying out the classical discussion stage online because it could not ensure the involvement of all students. Therefore, the teacher divides students into small groups and stimulates all group members to be involved in the discussion. The teacher distributes students with various kinds of cognitive abilities, so that there are students who are intelligent, active, passive, and need tutoring in one group. The teacher ensures that all students in the group are involved in the discussion and ultimately understand the concept of environmental conservation.

Some teachers carry out these stages synchronously through the google meet platform because they can meet face to face virtually with students, so students can discuss more actively in discussions. However, some teachers carry out this stage asynchronously through the google classroom platform, where students discuss through the comments column to agree on the answers to pre-learning questions as group answers. Through google classroom, students can independently identify which parts of the material are easy and difficult because all student answers can be read by anyone on the google classroom forum (Rahmatsyah \& Dwiningsih, 2021; Zhao, et al., 2020).

This is beneficial for students and they also want to be able to read all answers indefinitely and can be done repeatedly in google classroom. Discussion stage, train and develop student competencies in the realm of knowledge and thinking skills. This stage stimulates students to think critically and collaborate with friends to agree on answers to pre-learning questions given by the teacher so that students get an agreement on the correct answer (Satria \& Sopandi, 2019). In addition to developing critical thinking skills, students are instilled a character of cooperation and respect for the opinions of friends.

In the fourth stage, namely the explaining stage, students convey their group answers in the class forum through the google meet platform synchronously. The teacher stimulates students to ask questions, argue, respond to or add to what other students said during the presentation. At this stage, the teacher acts as a moderator to determine which group will present, ask questions, or other things to clarify the material. In addition to being a moderator, the teacher can act as a presenter if in this activity all students cannot answer questions asked by other students, and provide reinforcement regarding the concept of the material being discussed, and respond to student opinions. This stage trains students to be able to have communicative thinking skills so that students can communicate the 
results of group discussions that have been carried out at a later stage (Sukardi, et al., 2021). Activities at this stage foster student character to be confident in delivering the results of the discussion.

In the last stage, namely the making stage, students are encouraged to think about creative ideas. Student activities at this stage are approving, realizing, reporting product ideas. Students work in groups and present their progress synchronously or asynchronously through the Google Meeting or Google Classroom platforms. Teachers cannot monitor this moment directly but students can report what they have done through the Google Meeting or Google Classroom platforms. This stage stimulates students to develop creative ideas related to environmental preservation and development goals to be achieved. The creative ideas presented by the students varied greatly, starting from making recycled portable trash cans, making pictures telling stories about clean water and proper sanitation to making bicycle services from home to school for students located at home near the school. Activities at this stage stimulate students to come up with ideas to be able to find solutions to environmental problems that occur, these ideas will foster environmentally friendly behavior that will be applied in everyday life.

Based on the findings obtained from the five stages, the RADEC learning model encourages students to improve students' understanding of the concept of environmental conservation, develop various 21stcentury skills such as critical, creative, collaborative, and communicative thinking, and foster environmentally friendly attitudes and behaviors in everyday lifeday. These three competencies are ESD competencies that are developed for students so that students can apply the principles of sustainable development in the dimensions of environmental preservation in everyday life from an early age. Habit from an early age, it is expected that sustainable attitudes and values will be internalized in students. These attitudes and values will encourage everyone to live a life with the principles of sustainable development so that they can overcome various environmental problems (Maurer et al., 2020). The description of the five stages of the RADEC model in the implementation of ESD in elementary school science learning results can be seen in Figure 1.

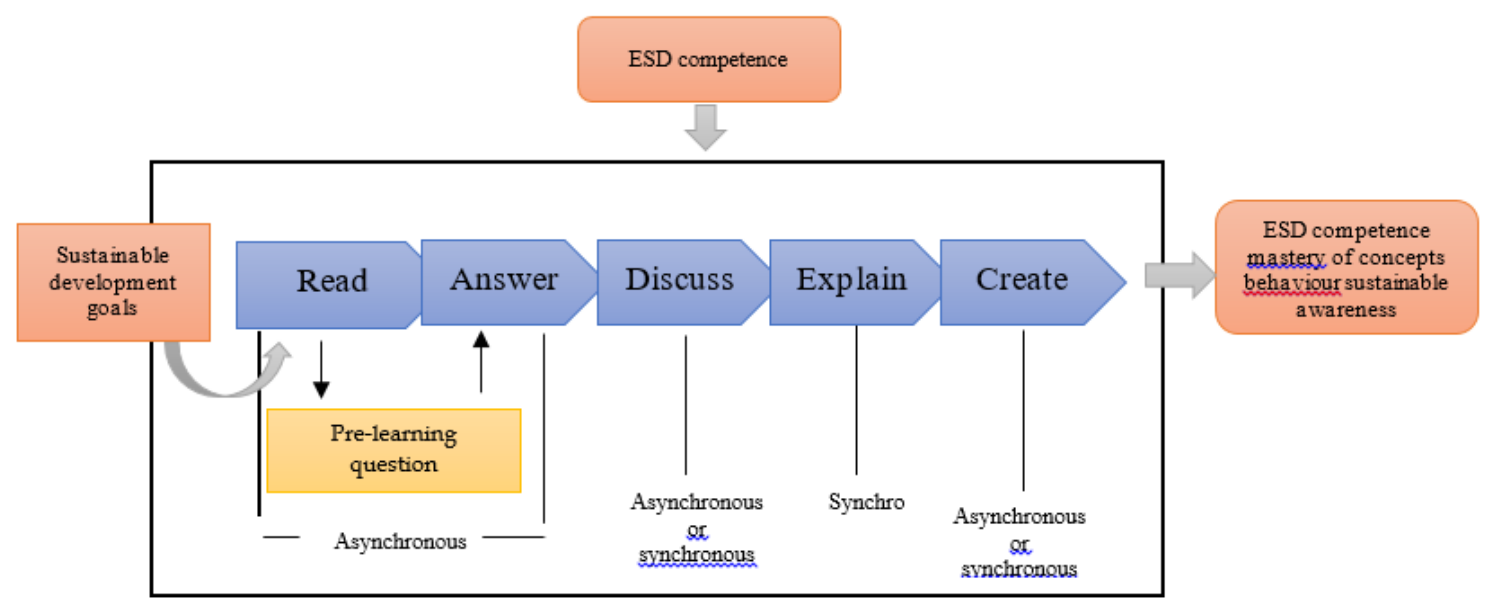

Figure 1. Stages of the RADEC Model in the Implementation of ESD in Science Learning

\section{Conclusion}

Education plays an important role in implementing sustainable development through learning in schools. Sustainable development goals need to be integrated with all subjects. The development objectives consist of three dimensions of sustainable development, namely environmental preservation, socio-culture, and economic development. The dimension of environmental preservation can be integrated into science learning. Science learning which is packaged in thematic learning at the elementary school level can provide opportunities in the process of implementing sustainable development education in the dimensions of environmental preservation holistically and comprehensively. Each Basic Competency can be arranged into indicators in the realm of knowledge, skills, and attitudes that apply the principles of sustainable development. Sustainable development in the dimension of environmental preservation is applied through the RADEC learning model. The RADEC model can stimulate students to learn actively, not only mastering the concept of environmental conservation but thinking skills and attitudes in preserving the environment and this model can be applied in synchronous and asynchronous online learning so it is suitable for use during the Covid-19 pandemic. 


\section{References}

Ali, M. (2017). Curriculum Development for Sustainability Education. Upi Press: Bandung.

Birdsall, S. (2015). Analysing teachers' translation of sustainability using a PCK framework. Environmental Education Research, 21(5), 753-776. https://doi.org/10.1080/13504622.2014.933776

Borup, J., Chambers, C., \& Srimson, R. (2019). Online teacher and on-site facilitator perceptions of parental engagement at a supplemental virtual high school. International Review of Research in Open and Distance Learning, 20(2), 79-95. https://doi.org/10.19173/irrodl.v20i2.4237

Cebrián, G., \& Junyent, M. (2015). Competencies in education for sustainable development: Exploring the student teachers' views. Sustainability (Switzerland), 7(3), 2768-2786. https://doi.org/10.3390/su7032768

Creswell, J. W. (2014). Four Edition Research Design: Qualitative, Quantitative, and Mixed Methods Approaches. University of Nebraska Lincoln.

Dhawan, S. (2020). Online Learning: A Panacea in the Time of COVID-19 Crisis. Journal of Educational Technology Systems, 49(1), 5-22. https://doi.org/10.1177/0047239520934018

Eilks, I. (2015). Science education and education for sustainable development - justifications, models, practices and perspectives. Eurasia Journal of Mathematics, Science and Technology Education, 11(1), 149-158.

https://doi.org/10.12973/eurasia.2015.1313a

Goleman, D., \& Barlow, Z. (2012). Ecoliterate: How Educators are Cultivating Emotional, Social an Ecological Intelligence. Jossey Bass. A Wiley Imprint. USA Healdsburg, CA: Watershed Media., 23-34.

Karlina, D., Sopandi, W., \& Sujana, A. (2020). Critical Thinking Skills of Fourth Grade in Light Properties Materials through the Radec Model. The 2nd International Conference on Elementary Education, 2(1), 1743-1753.

Komarudin, Rusman, \& Mohammad, A. (2019). Integration of Sustainable Development Education Concerning Environment Conservation into Senior High School Islamic Education Curriculum. Journal of Physics: Conference Series, 1179(1). https://doi.org/10.1088/1742$\underline{6596 / 1179 / 1 / 012063}$

Laurie, R., Nonoyama-Tarumi, Y., Mckeown, R., \& Hopkins, C. (2016). Contributions of Education for Sustainable Development (ESD) to Quality Education: A Synthesis of Research. Journal of Education for Sustainable Development, 10(2), 226242. https:// doi.org/10.1177/0973408216661442

Lestari, H., Setiawan, W., \& Siskandar, R. (2020). Science
Literacy Ability of Elementary Students Through Nature of Science-based Learning with the Utilization of the Ministry of Education and Culture' s " Learning House ". Journal of Research in Science Education, 6(2), 215-220. https://doi.org/10.29303/ippipa.v6i2.410

Lestari, H., \& Widodo, A. (2021). Peranan Model Pembelajaran Nature of Sains Untuk Meningkatkan Pemahaman Sains Siswa Sekolah Dasar. Jurnal Cakrawala Pendas, 7(1), 1-9. http://dx.doi.org/10.31949/jcp.v7i1.2425

Lestari, H., \& Siskandar, R. (2020). Cultivating Green Behavior of Eco Literation-Based Elementary School Students during the COVID-19 Pandemic. Jurnal Penelitian Pendidikan IPA, 7(1), 49-53. https://doi.org/10.29303/ippipa.v7i1.477

Listiawati, N. (2011). Relevansi Nilai-Nilai ESD dan Kesiapan Guru Dalam Mengimplementasikannya di Sekolah. Jurnal Pendidikan Dan Kebudayaan, 17(2), 135. https://doi.org/10.24832/jpnk.v17i2.13 [Indonesian]

Lui, A. (2012). Teaching in The Zone. An Introduction to working within the Zone of Proximal Development (ZPD) to drive effective early childhood instruction.

Maurer, M., Koulouris, P., \& Bogner, F. X. (2020). Green awareness in action-how energy conservation action forces on environmental knowledge, values and behaviour in adolescents' school life. Sustainability (Switzerland), 12(3). https://doi.org/10.3390/su12030955

Murniningtyas, A., \& Endah, S. A. (2018). Tujuan Pembangunan Berkelanjutan di Indonesia: Konsep, Target dan Strategi Implementasi. Unpad Press. Universitas Padjajaran [Indonesian]

Pauw, J. B. de, Gericke, N., Olsson, D., \& Berglund, T. (2015). The effectiveness of education for sustainable development. Sustainability (Switzerland), 7(11), 15693-15717. https://doi.org/10.3390/su71115693

Peters, T., Schubeck, K., Hopkins, K., Peters, B. T., Schubeek, K., \& Hopkins, K. (2014). Thematic Theory and Practice Approach at the Aleknagik All classes at the K-8 Aleknagik School in southwest Alaska revolve around a theme that has a science or a have been heartening. Phi Delta Kappan, 76(8), 633-636. Retrieved from. https://eric.ed.gov/?id=EJ501265

Prabawani, B., Hanika, I. M., Pradhanawati, A., \& Budiatmo, A. (2017). Primary schools eco-friendly education in the frame of education for sustainable development. International Journal of Environmental and Science Education, 12(4), 607-616. Retrieved from. http://www.ijese.net/makale/1831.html

Pratiwi, N., Sopandi, W., \& Rosdiono, M. (2018). the Students ' Conceptual Understandings on Global 
Warming Through Read-Answer-DisscussExplain-and Create (Radec) Learning. International Conference on Elementary Education Universitas Pendidikan Indonesia, 635-639.

Rahmadani, D., Chastanti, I., \& Harahap, D. A. (2021). Parents' Role in Biology Learning During the Covid 19 Pandemic. Jurnal Penelitian Pendidikan IPA, 7(2), 137-142. https://doi.org/10.29303/jppipa.v7i2.583

Rahmatsyah, S.W., \& Dwiningsih, K. (2021). Development of Interactive E-Module on The Periodic System Materials as an Online Learning Media. Jurnal Penelitian Pendidikan IPA, 7(2), 255261. https://doi.org/10.29303/jppipa.v7i2.582

Richardson, J. W., Lingat, J. E. M., Hollis, E., College, R., \& Pritchard, M. (2020). Shifting teaching and learning in online learning spaces: An investigation of a faculty online teaching and learning initiative. Online Learning Journal, 24(1), 67-91. https://doi.org/10.24059/olj.v24i1.1629

Satria, E., \& Sopandi, W. (2019). Applying RADEC model in science learning to promoting students' critical thinking in elementary school. Journal of Physics: Conference Series, 1321(3). https://doi.org/10.1088/17426596/1321/3/032102

Setiawan, D., Hartati, T., Sopandi, W., \& Indonesia, U. P. (2020). Effectiveness of Critical Multiliteration Model With Radec Model on the Ability of Writing Explanatory Text. EduHumaniora | Jurnal Pendidikan Dasar Kampus Cibiru, 12(1), 1-14. https://doi.org/10.17509/eh.v12i1.17445

Siti, Z. (2016). Keterampilan Abad Ke-21: Keterampilan Yang Diajarkan Melalui Pembelajaran. Seminar Nasional Pendidikan, 2, 1-17. https://doi.org/10.1021/acs.langmuir.6b02842 [Indonesian]

Sopandi, Agustin, M., Gumala, Y., Anggraeni, P., \& Rahayu, A. H. (2020). Improving Creative Thinking Ability of Prospective Elementary School Teachers through Read-Answer-Discuss-Explainand Create (RADEC) Project-Oriented Learning Model. The 2nd International Conference on Elementary Education, 2(1), 1298-1308.

Sopandi, W. (2019). Sosialisasi dan Workshop Implementasi Model Pembelajaran RADEC Bagi Guru-Guru Pendidikan Dasar dan Menengah. PEDAGOGIA: Jurnal Pendidikan, 8(1), 19. https://doi.org/10.21070/pedagogia.v8i1.1853 [Indonesian]

Sukardi, R. R., Sopandi, W., \& Riandi, R. (2021). Repackaging RADEC learning model into the online mode in science class. Journal of Physics: Conference Series, 1806(012141), 1-7. https://doi.org/10.1088/1742- $\underline{6596 / 1806 / 1 / 012142}$

Sukmawati, D., Sopandi, W., \& Sujana, A. (2020). The Application of Read-Answer-Discuss-Explain-and Create (Radec) Models to Improve Student Learning Outcomes in Class V Elementary School on Human Respiratory System. The 2nd International Conference on Elementary Education, 2(1), 1734-1742.

Supriatna, N., Romadona, N. F., Saputri, A. E., Darmayanti, M., \& Indonesia, U. P. (2018). Implementasi Education for Sustainable Development (ESD) Melalui Ecopedagogy Dalam Pembelajaran Tematik Terpadu Di Sekolah Dasar. Primaria Educationem Journal, 1(2), 80-86. http://journal.unla.ac.id/index.php/pej/article/ view $/ 1077 / 748$

UNESCO. (2017). Education for Sustainable Development Goals: Learning Objectives; UNESCO: Paris, France. In International Journal of Trend in Scientific Research and Development (Vol. 2, Issue 1). https://doi.org/10.31142/ijtsrd5889

Webb, P. I. \& Pearson, P. J. (2012). Creative unit and lesson planning through a thematic/integrated approach to Teaching Games for Understanding (TGfU). New Zealand Physical Educator, 45 (3), 1722., 45(3), 17-22. Retrieved from. https://ro.uow.edu.au/sspapers/93/

Xiaoqiao, C. (2020). Challenges of "School's Out, But Class's On" to School Education: Practical Exploration of Chinese Schools during the COVID19 Pandemic. Science Insights Education Frontiers, 5(2), 501-516. https://doi.org/10.15354/sief.20.ar043

Zandvakili, E., Washington, E., Gordon, E., \& Wells, C. (2018). Mastery Learning in the Classroom: Concept Maps, Critical Thinking, Collaborative Assessment (M3CA) Using Multiple Choice Items (MCIs). Journal of Education and Learning, 7(6), 45. https://doi.org/10.5539/jel.v7n6p45

Zhao, N., Zhou, X., Liu, B., \& Liu, W. (2020). Guiding Teaching Strategies with the Education Platform during the COVID-19 Epidemic: Taking Guiyang No. 1 Middle School Teaching Practice as an Example. Science Insights Education Frontiers, 5(2), 531-539. https://doi.org/10.15354/sief.20.rp005 